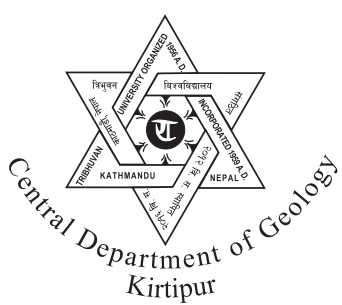

\title{
Geology and rockmass condition of Dhulikhel-Panchkhal area, Kavre District, Central Nepal Lesser Himalaya
}

\author{
Prem Nath Paudel and *Naresh Kazi Tamrakar \\ Central Department of Geology, Tribhuvan University, Kirtipur, Kathmandu, Nepal
}

\begin{abstract}
A geological mapping was carried out and the rock mass characteristics of the Lesser Himalayan rocks distributed in the Dhulikhel-Panchkhal area (Kavre Distric) were studied along with their physical and mechanical properties. The lithological units distributed in the study area belong to the Benighat Slate of the Upper Nawakot Group and the Bhimphedi Group as separated by the Chak-Rosi Thrust. The lithological units strike NW-SE and dip southwards forming the eastern closure of part of the northern limb of the Mahabharat synclinorium. The area comprises mainly micaceous quartzite, psammitic schist, metasandstone and metasiltstone. Micaceous quartzite is a rock type of the Kalitar Formation, Chisapani quartzite and the Markhu Formation. The Markhu quartzite is slightly calcareous. Psammitic schist is a rock type of the Kulekhani Formation and the Markhu Formation. Metasandstone and metasiltstone are the rock types of the Tistung Formation. The rock masses consist mainly of three to four major joint sets including the joint parallel to foliation. The discontinuity characteristics indicate that the rocks are blocky in nature, and nearly smooth to rough surface with soft filling aperture. The rock mass is nearly fresh, indurated and stiff. The slopes are influenced by stable and unstable wedges, plane and toppling failures. The rock masses are classified into fair to good rock classes according to rock mass rating system.
\end{abstract}

\section{INTRODUCTION}

Rocks and sediments are main sources of construction materials. Currently, in Kathmandu and Banepa valleys (Fig. 1), the most of the crushed stone (aggregate) is supplied from Kabhre area. The Precambrian to Paleozoic rocks of the Kathmandu Complex (Stöcklin, 1980) are the major sources of aggregate in Kabhre area. Studying geology and rock mass characteristics are prime factors for surveying and exploring potential resources of construction materials. Geology recognizes the lithological distribution and their structures. The construction materials are derived from lithological units which have their own rockmass characteristics

*Corresponding author:

E-mail address: nktam555@gmail.com governed by features of discontinuities, strength, Rock Quality Designation, and weathering condition (Bieniawski, 1989). These features are required to be determined for evaluating the quality of the construction material.

Stöcklin and Bhattarai, 1977 and Stöcklin, 1980 divided the rocks of the Kavre area into two complexes: the crystalline high-grade metasedimentry Kathmandu Nappe (Complex) and beneath it the non-crystalline, low-grade metasedimentry Nawakot Complex, and have recognized the Thrust contact between the Kathmandu Complex and the Nuwakot Complex as a "Chak-Rosi Thrust" which is a direct continuation of the Mahabharat Thrust. Kansakar (1980) gave a detailed interpretive account of the structural geology of the northeastern part of the study area between the Indrawati River and 


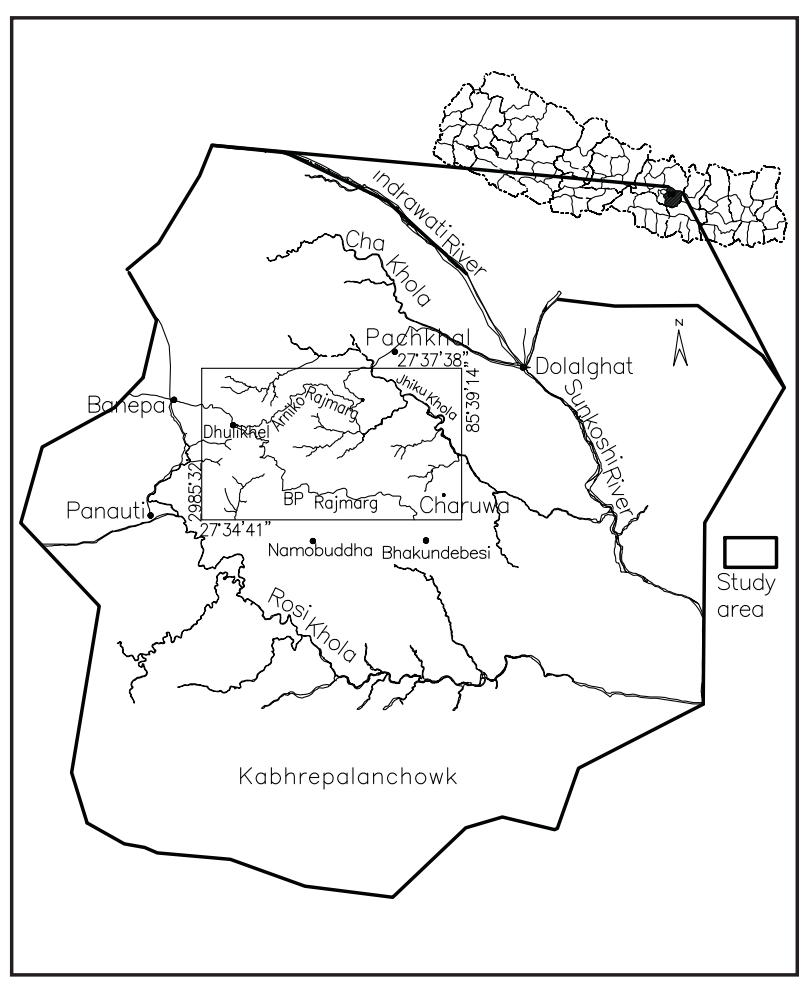

Fig. 1 Location map of the study area.

the Jhiku Khola. Kayastha (1995) studied geology of the Timal Dada and its surrounding area. The more detail study of geology of the Jhiku Khola watershed area was carried out by Tamrakar et. al. (1997), who prepared geological map of the Jhiku Khola watershed area, a generalized lithostrtigraphic column of the Lesser Himalayan rocks in the Kabhre area, and detailed columnar sections of units of the Bhimphedi group rocks at different sections.

\section{METHODOLOGY}

Various rock types were recorded along with their attitudes and descriptions to compile a 1:25000-scale geological map. Samples for microscopic study and laboratory testing were also collected. The engineering geological study of the rock outcrops, the lithological characteristics, rock mass properties, weathering grade, and indurations were studied during the field work. The rock outcrops were classified according to the RMR system of Bieniawski (1989). The kinematic analysis of slope instability was also made.
The representative rock samples were cut perpendicular or nearly perpendicular to foliation plane in the laboratory and thin sections were prepared to examine for mineralogical composition, texture and microstructural features present in the rocks. From the block of samples cores were drilled out in the laboratory. The cores were used of diameter $2.51 \mathrm{~cm}$. Among two sets of cores one set sample was used for determining density and water absorption values following Caliper and saturation method (ISRM 1979), while other was used in determining point load strength index, Is. The cores with foliation or stratification normal to their axes where loaded along the core axis. The calculation was made thenafter for uniaxial compressive strength (UCS) derived from point-load strength index, Is(54) after Hassani et. al. (1980) using the relation: UCS $=\operatorname{Is}(54)$ $\times 29$ to determine the intact rock strength classification after Bieniawski (1975).

\section{GEOLOGY OF THE DHULIKHEL- PANCHKHAL AREA}

The rocks of the study area can be assigned in to the Kathmandu Complex and the Nawakot Complex. These two Complexes are distinctly separated by the ChakRoshi Thrust which is a part of the Mahabharat Thrust (Stocklin and Bhattarai 1977). The geological map of the study area is shown in Fig. 2, and the generalized lithostratigraphic succession is shown in Fig. 3. Mainly the Bhimphedi group and the lower unit of the Phulchoki group (i.e., Tistung Formation) of the Kathmandu Complex rocks are distributed in the study area. Small part of the upper unit of the Upper Nawakot Group (i.e. Benighat Slate) is also exposed in the footwall of the Chak-Rosi Thrust at the NE of the study area. The essential lithological differences between the Kathmandu and the Nawakot Complexes are the metamorphic grade. The Kathmandu Complex consists of relatively highgrade metamorphic rocks such as garnetiferous mica schist, micaceous quartzite and calcareous schist. The Timal Granite Gneiss is intruded within the Bhimphedi Group at the SE part of the study area. The unmetamorphosed or weakly metamorphosed rocks of the Tistung Formation of the Phulchouki Group are well exposed at the western part of the study area. The valley filling soft sediment is also widely distributed in the present study area. 


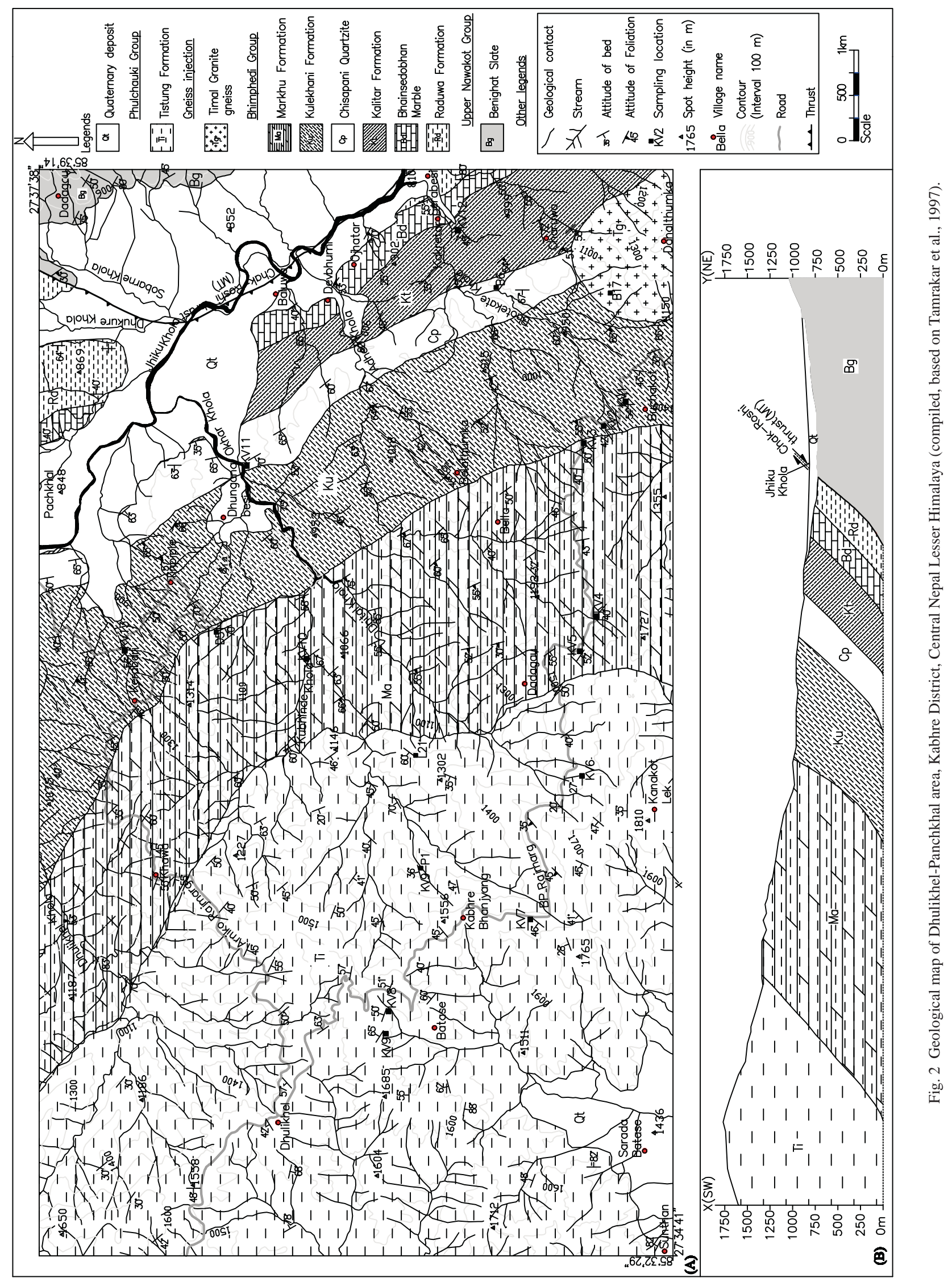




\begin{tabular}{|c|c|c|c|c|c|}
\hline omplex & Group & Formation & \begin{tabular}{|l|}
$\begin{array}{l}\text { Thick- } \\
\text { ness }\end{array}$ \\
\end{tabular} & Litho-index & Lithology (description) \\
\hline \multirow{8}{*}{ 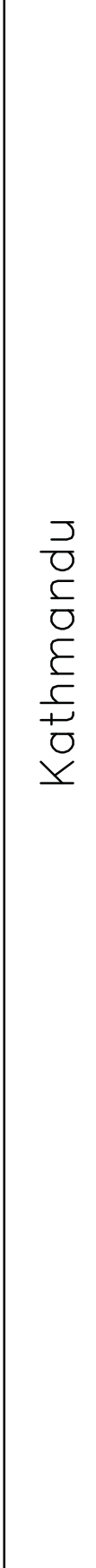 } & 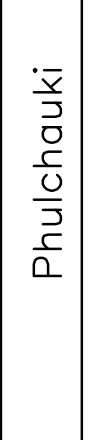 & 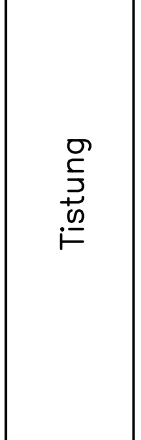 & $7-$ & 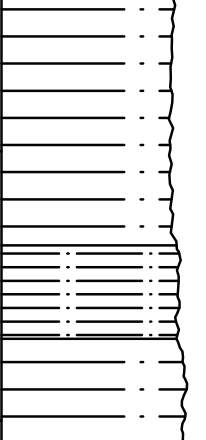 & $\begin{array}{l}\text { Thin to thick bedded, laminated, fine } \\
\text { grained, micaceous, light grey, } \\
\text { sandstone and siltstone interbedded } \\
\text { with phyllite horizons } \\
\text { Intercalation of light green grey phyllite } \\
\text { and light grey to dark grey, fine- to } \\
\text { medium- grained, micaceous } \\
\text { metasandstones } \\
\text { Thin to medium bedded, biotite rich } \\
\text { quartzite, veins and lenses of pegmatites }\end{array}$ \\
\hline & \multirow{7}{*}{ 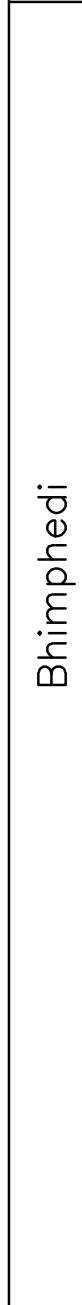 } & 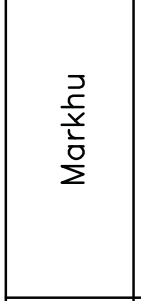 & & 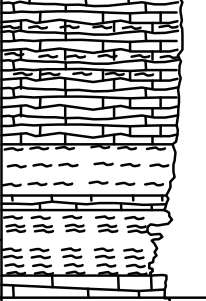 & $\begin{array}{l}\text { Competent, thick to medium bedded, dark } \\
\text { grey, finely crystalline calcareous quartzite } \\
\text { with veins and lenses of granite-pegmatite } \\
\text { Foliated, bluish grey, medium bedded, } \\
\text { calcareous mica rich quartzite and schist } \\
\text { Calcareous quartzite }\end{array}$ \\
\hline & & $\begin{array}{l}\bar{c} \\
0 \\
\frac{c}{x} \\
\frac{x}{d} \\
\frac{1}{3}\end{array}$ & & & $\begin{array}{l}\text { Highly biotite rich, dark grey foliated, } \\
\text { micadeius quartzite consisting veins of } \\
\text { pegmatites and augen gneisses. } \\
\text { Competent schist and quartzite with } \\
\text { veins of pegmatites. }\end{array}$ \\
\hline & & $\begin{array}{l}\text { Chisapani } \\
\text { Quartzite }\end{array}$ & & & $\begin{array}{l}\text { Thin to medium bedded, light grey coarse, } \\
\text { micaceous quartzite schist with augen gneiss }\end{array}$ \\
\hline & & 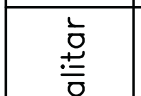 & & 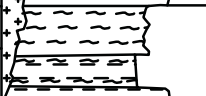 & $\begin{array}{l}\text { Micaceous quartzite and garnetiferous } \\
\text { schist with augen gneiss }\end{array}$ \\
\hline & & & & 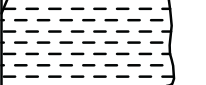 & $\begin{array}{l}\text { Micaceous quartzite intercalating with } \\
\text { green mica-schist. }\end{array}$ \\
\hline & & 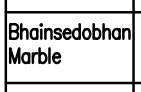 & $260 \mathrm{~m}$ & 至 & $\begin{array}{l}\text { Marble consisting of some micaceous quartzite, } \\
\text { schist and calcareous quastzite }\end{array}$ \\
\hline & & \begin{tabular}{l}
0 \\
3 \\
3 \\
0 \\
0 \\
\hdashline
\end{tabular} & . & 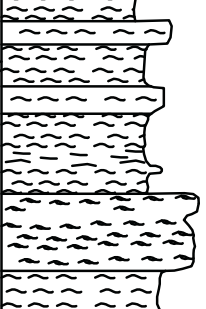 & $\begin{array}{l}\text { Dark grey, highly foliated, garnetiferous } \\
\text { schist and some horizons of thin bedded, } \\
\text { slabby, white biotite-muscovite quartzite } \\
\text { Foliated, banded augnen gneiss with } \\
\text { bands of white quartzites and schist. } \\
\text { Garnetiferous schist with quartz veins }\end{array}$ \\
\hline $\begin{array}{l}+ \\
\stackrel{0}{ } \\
\stackrel{y}{0} \\
\\
3 \\
0 \\
Z\end{array}$ & 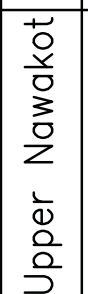 & 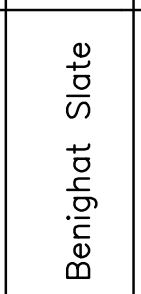 & $0 \mathrm{~km}=$ & 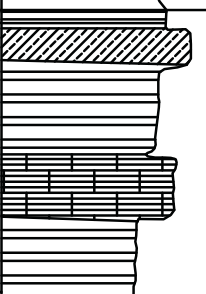 & $\begin{array}{l}\text { Dark green grey (chloritic) slate/phyllite } \\
\text { Basic rock } \\
\text { Dark greenish grey phyllitic slate } \\
\text { Highly porous limestone with intercalation } \\
\text { of some phyllite and slate } \\
\text { Crenulated phyllitic slates. }\end{array}$ \\
\hline
\end{tabular}

Fig. 3 Generalized lithostratigraphic column of the Lesser Himalayan rocks, Dhulikhel-Panchkhal area, Kabhre District, Central Nepal Lesser Himalaya. 


\section{Upper Nawakot Group}

\section{Benighat Slate}

Benighat Slate is the uppermost unit of the Upper Nawakot Group. The formation is found in the footwall of the Chak-Rosi Thrust at the NE part of the study area, i.e., at the ridge and valley slopes of Palanchowk. Most of the part of this formation is covered by the soft sediments of the Jhiku Khola. The Benighat Slate consists of black carbonaceous slate, phyllite and calcareous phyllite and quartzite. The outcrop is well exposed around the Dadagau Village and consists of thinly foliated dark green grey to light grey muscovite-sericite phyllite. The thinly bedded white calcareous quartzite bands are intercalated with phyllite. The highly laminated light grey and porous limestones are frequently found.

\section{Bhimphedi Group}

The rocks of the Bhimphedi Group are underlain by the Upper Nawakot Group (mainly Benighat Slate) as separated by the Chak-Rosi Thrust. In the south eastern part of the Bhimphedi Group intrusive body of the Timal Granite Gneiss is present. This intrusion transects the Kalitar formation, the Chisapani Quartzite and the Kulekhani Formation, in the study area.

\section{Raduwa Formation}

The Raduwa formation is the basal formation of the Bhimphedi Group. Garnetiferous micaschist and micaschist with some micaceous quartzite bands are the main rock types. The formation is exposed in the right bank of the Jhiku Khola, at the Baluwa village, Ojhatar, Serabesi and along the Dhukure Khola. At these places the exposure consists of highly weathered coarsely crystalline micaschist and micaceous quartzites. The lower part of this formation consists of light grey banded augen gneiss. The banded gneiss is frequently found intercalated with quartzite and schist. The upper part of this formation consists of greenish grey, highly foliated schist intercalated with greenish grey quartzite. The thickness of this formation is about $1200 \mathrm{~m}$.

\section{Bhainsedobhan Marble}

The Bhainsedobhan Marble is transitional with the Raduwa Formation. It is well exposed in the stream at
Baluwa, Devbhumi and below the Ojhatar Village. The Jhikhu Khola sediments cover this formation at the northeastern part. The lower part of the formation consists of thin to medium banded, coarsely crystalline, grey to white marble. Dark grey calcareous, mica bearing quartzite is found in the middle part, whereas banded white marble intercalated with quartzite is exposed in the upper part of the formation. The thickness of the formation in the study area is about $260 \mathrm{~m}$.

\section{Kalitar Formation}

The outcrops of this formation are found around the Charuwa Village and in the upstream of the Bhotekate Khola and Kakretar. The Timal Granite Gneiss is intruded within this formation at south eastern part of the study area. The main rock types of this formation are psammitic schist and micaceous quartzite. The psammitic schist is medium to coarsely crystalline showing good schistosity, and is intercalated with quartzite. In this schist, biotite is the dominant mineral along with quartz, but muscovite, sericite and chlorite are also present in notable amount. Micaceous quartzite (KV12) from the right bank of the Bhotekate Khola is white to grey, medium to coarsely crystalline, fractured, strongly foliated, and strongly indurated. The model composition of the sample is quartz $74 \%$, biotite $14 \%$, muscovite $9 \%$, feldspar $1 \%$, and other minerals $2 \%$. The recrystallized quartz grains are coarse and anhedral, the biotite and muscovite grains

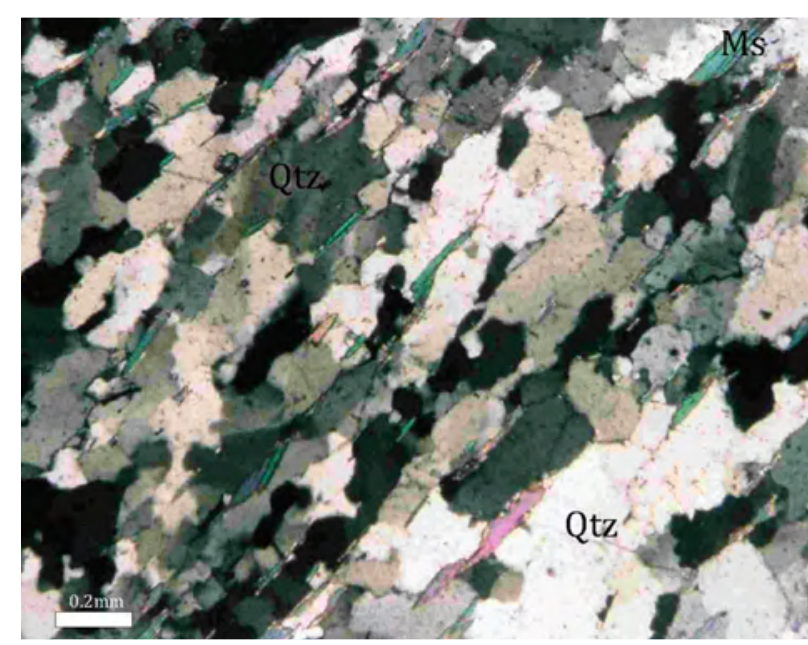

Fig. 4: Photomicrograph of micaceous quartzite (Sample KV12) showing preferred orientation of mica grains and elongate quartz grains parallel to foliation. Qtz $=$ Quartz, $\mathrm{Ms}=$ Muscovite, $\mathrm{Bt}$ $=$ Biotite. 


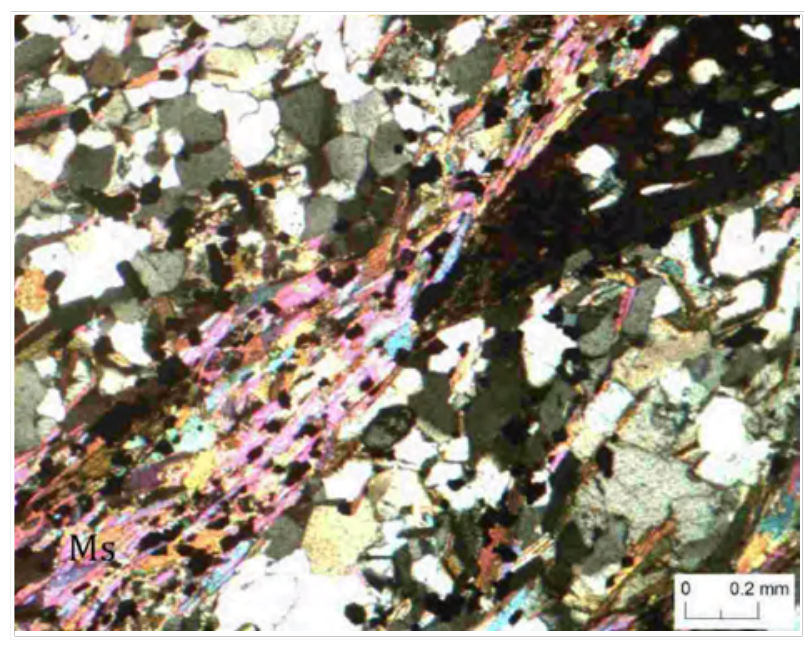

Fig. 5 Photomicrograph of quartzite showing preferred orientation of mica grains and subequant quartz grains (Sample B6). Qtz = Quartz, $\mathrm{Ms}=$ Muscovite, $\mathrm{Bt}=$ Biotite.

are very elongate. Suture and tangential contacts are observed among quartz grains (Fig. 4). The sample exhibits porphyroblastic texture. One set of strong foliation is distinctly defined by preferred orientation of mica minerals. The Jhiku Khola sediments cover this formation at the northern part. The thickness of this formation is about $800 \mathrm{~m}$.

\section{Chisapani Quartzite}

The Chisapani Quartzite consists of thin to thick bedded, slabby and white crystalline quartzite. This lithology is a good marker between the much darker quartzite and schist of the underlying Kalitar Formation and the overlying Kulekhani Formation. It is well exposed along the Bhotekate Khola, Adheri Khola, Okhar Khola, Jhiku Khola, Jhiku khola at the Tamaghat, Ariniko Rajmarg around the Dhunganabesi, and Ranipani. It is also affected by granite intrusion like in the Kalitar Formation at the southeastern part of the study area. The individual white quartzite varies from $2 \mathrm{~cm}$ to $20 \mathrm{~cm}$, and in some places up to $50 \mathrm{~cm}$. The thin to medium layers of mica schist bands are also intercalated with white quartzite in some places. The white quartzite (B6) consists predominantly of quartz, and subordinately of elongate biotite and muscovite, which define foliation. A modal composition after 200 grains counts is quartz $60 \%$, muscovite $15 \%$, biotite $15 \%$, feldspar $4 \%$, opaque and others $6 \%$ (Fig. 5). The quartz grains are fine- to medium-grained with sutured boundaries. Some of them are fractured and showing

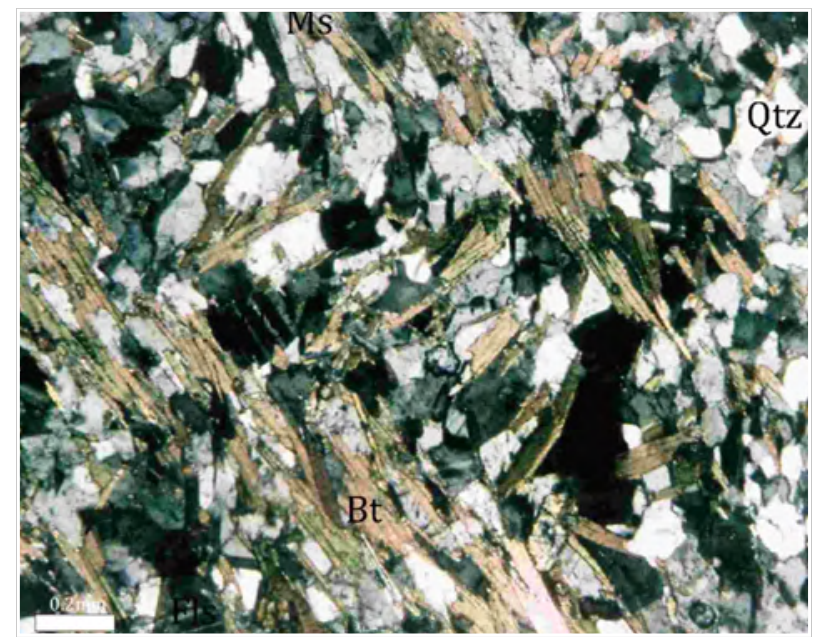

Fig. 6 Photomicrograph of schist (KV1) showing nearly subequant quartz and feldspar grains and elongate biotite-muscovite extending with two-set deformation, crenulated structures and heterogeneous distribution of quartz and mica. Qtz = Quartz, Ms = Muscovite, $\mathrm{Bt}=$ Biotite.

undulose to unit extinction. Some calcareous bands also occur in association with quartzite. The thickness of the Chisapani Quartzite is about $400 \mathrm{~m}$.

\section{Kulekhani Formation}

This Formation is well exposed along the BP Rajmarg at the SE, along the Arniko Rajmarg at the northern part, along the Okhor Khola, Adheri Khola, and around Belathanka. Along the BP Rajmarg below the Buchakot village, it mainly consists of laminated, dark grey finely crystalline micaceous quartzite, and schist. The individual thickness of the quartzite beds varies from $20 \mathrm{~cm}$ to 1 $\mathrm{m}$. Schist band thickness ranges from $30 \mathrm{~cm}$ to $1.5 \mathrm{~m}$. The psammitic schist (sample KV1) is grey to dark grey, fine- to medium- crystalline, banded to massive, foliated and indurated in handspecimen. Under petrological microscope, the modal composition is: quartz $41 \%$, biotite $31 \%$, muscovite $18 \%$, feldspar $3 \%$, chlorite $1 \%$, and other heavy and opaque minerals $6 \%$. The quartz and feldspar grains are nearly equant and anhedral and biotite-muscovite grains are elongated. Two-set deformation, crenulated structures and heterogeneous distribution of quartz and mica are the typical microstructural characters of this sample (Fig. 6). The quartz grains are moderately fractured and show slightly undulose extinction. Quartz grains are recrystallized and deformed. The grain contacts are tangential, indented and sutured. The cross-cut of biotite 


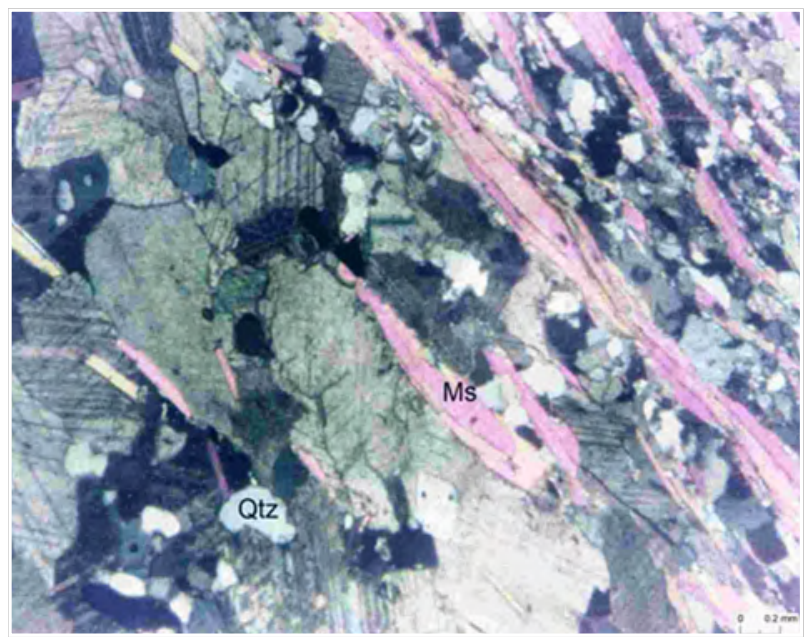

Fig. 7 Photomicrograph of siliceous marble of the Markhu Formation showing rhombohedral cleavage of calcite with elongated mica and fine grained quartz (Sample D51). Qtz = quartz. $\mathrm{Cal}=$ calcite, $\mathrm{Ms}=$ muscovite .

and muscovite are well developed and kink fold is present (Fig. 6). The quartz veins are frequently observed within the schist along the Ariniko Rajmarg. Tourmaline and pegmatite veins are present near Kerabari. The thickness of the Kulekhani Formation is about $1250 \mathrm{~m}$ in the study area.

\section{Markhu Formation}

This Formation in the study area is widely distributed along the BP Rajmarg, Arniko Rajmarg, Kubinde Khola, Dhital Khola, Dhulikhel Khola, Bella Village and Dadagaun Village. In this formation, green grey to light grey, medium to massive bedded, fine- to mediumgrained calcareous schist and micaceous calcareous quartzite are predominant. The light grey, thin beds of quartzite are also intercalated with calcareous schists. The mica content in schist is less than in the Kulekhani Formation. The foliation is slightly developed in schist and quartzite. The thickness of this Formation in the study area is about $1200 \mathrm{~m}$.

The typical exposure of the Markhu Formation is exposed at the stream channel about $50 \mathrm{~m}$ west from the Tinpiple temple, $1 \mathrm{~km}$ milestone from Tinpiple-Khawa road section. The outcrop consists of crystalline bands of marble intercalated with dark grey calcareous schist. The calcareous quartzite and schist were frequently found along the Arniko Rajmarg from Kerabari to Khawa village. The modal composition

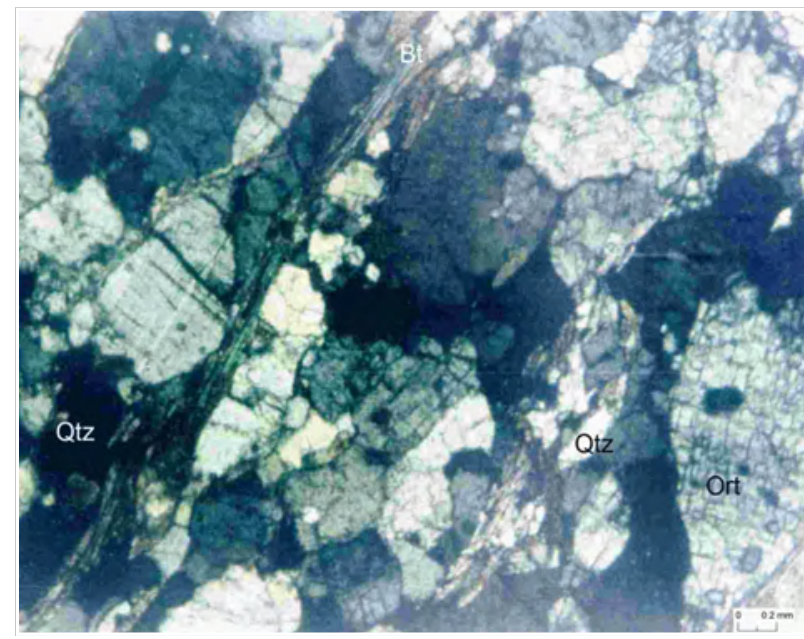

Fig. 8 Photomicrograph of gneiss showing orthoclase grains and the gneisosity defined by extension of biotites (Sample B17). $\mathrm{Qtz}=$ quartz, Ort = orthoclase, $\mathrm{Bt}=$ biotite.

after 200 grains counts is calcite $65 \%$, mica $15 \%$, quartz $17 \%$ and other minerals $3 \%$. The calcite grains are coarsely crystalline, and show perfect cleavage (Fig. 7). Mica grains are elongated and needle shaped showing 1 set of perfect foliation. Quartz grains are very finegrained.

\section{Timal Granite Gneiss}

In association with the medium-grade crystalline rocks of the Kalitar Formation, the Chisapani Quartzite and the Kulekhani Formation, one granitic body is intruded in the southeast part of the study area, exposed at the uphill side of the Charuwa village and Dahalthumka top hill of Timaldada. The contact with the country rock of the granitic gneiss is mostly discordant cutting across schistosity plane. The regional metamorphic pattern is not affected by the injection except near their vicinity. The outcrop of the granitic body is highly weathered and it consists of quartz, feldspar, biotite, muscovite and tourmalline. The foliation is developed within the granitic body. The outcrop in some places consists of grey with white spots, coarse grained, porphyroblast augen structure of feldspar and quartz. The Sample B17 from the Timal Granite Gneiss shows porphyritic texture with orthoclase grains (Fig. 8 ). The model composition after 200 grains counts is orthoclase $55 \%$, quartz $25 \%$, biotite $10 \%$, tourmaline $7 \%$ and other $3 \%$. The gneissosity is developed and ribbon-like quartz grains are found. The orthoclase 


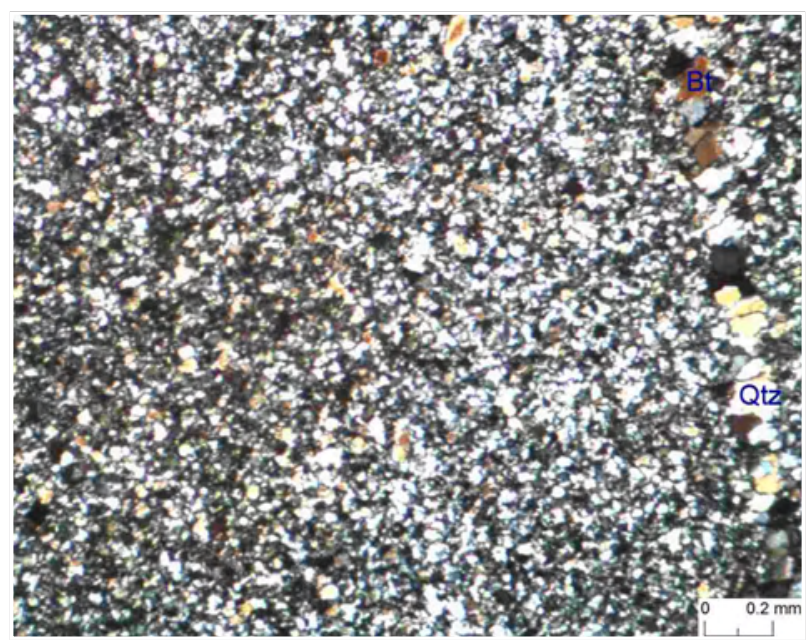

Fig. 9 Photomicrograph of metasiltstone with quartz vein at the right side of the photomicrograph (Sample L21).

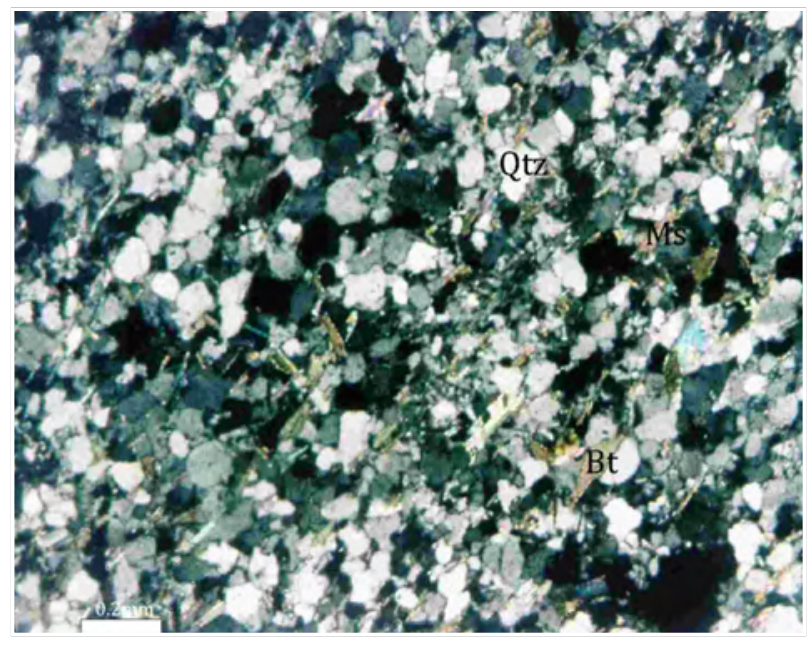

Fig. 10 Photomicrograph of metasandstone showing angular to sub rounded quartz and elongated mica grains (Sample KV9P1). Qtz = Quartz, Ms = Muscovite, Bt = Biotite.

grains are coarse and highly fractured (Fig. 8).

\section{Phulchauki Group}

\section{Tistung Formation}

The Tistung Formation mainly consists of clastic sequences of metasandstone, metasiltstone, phyllite and slate. Some calcareous metasandstone beds are interbedded with phyllites. This formation is widely distributed giving well exposed outcrops along the BP Rajmarg from the Dhulikhel to Dadagau, Araniko Rajmarg from the Dhulikhel to Khawa village, along the Kabhrebhyang-Namobuddha road section, north and eastern parts of Dhulikhel, around Batase and the Sunthan village.

The sample L21 has a modal composition after 200 grains counts, of quartz $65 \%$, feldspar $12 \%$, chlorite $8 \%$, sericite $6 \%$, mica $5 \%$ and other $4 \%$. It consists of very fine-grained equigranular mass of quartz grains with chlorite which poorly defines the foliation. Two quartz veins having coarse crystal of quartz are present. Among two, one vein is clearly seen in photomicrograph (Fig. 9). Some mud and silt matrix are visible. Subangular to subrounded detrital quartz with some recrystallized quartz polygons are also visible.

The sample of metasandstone (KV9-P1) has a modal composition (after 200 grain counts) of quartz $70 \%$, chlorite $8 \%$, mica $15 \%$ and feldspar $2 \%$ and other $5 \%$. It consists of fine-grained equigranular mass of quartz grains with mica and chlorite. The preferred orientation of mica defines the foliation developed in metasandstone (Fig. 10). The angular to subrounded detrital quartz grains having unit extinction are visible.

\section{Quaternary deposits}

The quaternary deposits are widely distributed in the study area. Mainly along the Jhiku Khola, in the Sarada Batase valley and western parts of Dhulikhel the sediments of sand, silt and clay cover the area. The gravel, pebbles to boulder sized sediments are distributed along the Kubinde Khola, Dhital Khola, Adheri Khola, Okhar Khola, Bhotekate Khola, Dhulikhel Khola and almost all tributaries of the Jhiku Khola.

\section{GEOLOGICAL STRUCTURES}

The study area is an eastern closure of the Mahabharat synclinorium. The dipping of beddings at the northern part is towards SW, the rocks are dipping towards west at the eastern part. At the vicinity of the Namobuddha, Kabhrebhyang and Batase, the rocks are dipping towards northwest. The study area can be tectonically separated into two distinct divisions; the Kathmandu Complex and the Nawakot Complex separated by the Chak-Roshi Thrust which is a part of the Mahabharat Thrust (MT). It is NW- SE trending thrust. It runs along the Jhiku 
Khola and bends to the Sobarne Khola from Baluwa. The minor structures like small-scale folds, crosslaminae in metasandstone of the Tistung Formation are present. Several quartz veins are found in the Kalitar Formation schist. The veins are concordant in some places and discordant in other places. The quartz veins and pegmatite veins are also present in the Markhu Formation and the Kulekhani Formation.

\section{ROCK MASS CHARACTERISTICS}

\section{Discontinuity characteristics}

Rock masses are heterogeneous and anisotropic because of differing rock types, presence of discontinuities and varying degree of weathering. The discontinuities are plane of weakness in rock masses created by jointing, faulting, cleavage, bedding surfaces and well developed metamorphic foliations. The presence of discontinuities can have a profound effect on the bulk strength of the rock mass and can be highly influential in terms of its stability. Orientation, spacing, continuity, surface characteristics, separation of discontinuity surfaces, accompanying thickness and the nature of infilling materials present are the most consistently measured joint properties (Bieniawski, 1989). The discontinuities in rock masses in the study area are influenced by these characteristics. The rock mass characteristics were measured at thirteen locations of different lithological formations. These locations are shown in Fig. 2 and the measurements are tabulated in the Table 1.

The data show that three joint sets with bedding joint are prominent in the study area. Four joint sets with bedding joints were measured at locations KV8, KV10 and KV12. Most of the bedding joints are dipping towards SW with the dip amount 270 to $70^{\circ}$. At the location KV8 and KV9 the bedding joints are oriented towards NE with dip amount $50 \mathrm{o}$ and $65^{\circ}$, respectively. The NW dipping bedding joints were measured at the locations KV7 and KV13 having dip amount $42^{\circ}$ and $65^{\circ}$, respectively. The other major joint sets are oblique to perpendicular with bedding joints at almost all locations. The dip amount varies from $22^{\circ}$ to $85^{\circ}$. The presence of more joints and fractures is favorable for aggregate excavation.

The spacing of discontinuity data measured from the rocks of the study area shows that the spacing ranges from $5 \mathrm{~cm}$ to $2 \mathrm{~m}$. These spacing can be categorized into very close to wide spacing. Most of the bedding and foliations contain close to moderate spacing. Only the outcrops at the locations KV8, KV4 and KV11 contain spacing $<6 \mathrm{~cm}$ in some beddings, i.e. very close spacing. The spacing in other joints ranges from $8 \mathrm{~cm}$ to $2 \mathrm{~m}$ and can be categorized as close to wide spacing. These types of spacing distribute the rock mass into number of blocks. In the field the persistency of discontinuities was clearly observed and tabulated in Table 1. Almost all the beddings are persistent. They range from high to very high persistence but at the location KV3 and KV10 the beddings are discontinuous. They lie within medium persistence. Most of joints are discontinuous to few continuous. They lie within medium to high persistency. The persistency of discontinuities defines low stability of rock mass that means it is easy to excavate. Thus, the surfacial portions would be easy to excavate than others.

Surface characteristics of rock mass were identified by comparing with waviness and roughness profile after Barton and Choubey (1977). According to the field observation the roughness lie within 4-6 to 14-16. It means that the discontinuity surface varies from smooth to rough. The roughness of bedding and foliation surface lies between 4-6 and 8-10 and other joints surface lies between 6-8 and 12-14. Comparatively, the roughness of bedding and foliation planes is slightly smoother than other joint planes and more failures occur along the bedding and foliation planes. The joint aperture (width) ranges from $<0.5 \mathrm{~mm}$ to $10 \mathrm{~mm}$ meaning that the width is moderate open to very wide joints. The joint separation at the locations KV9, KV13 and KV12 contain low aperture in some joints and very wide aperture (about $1 \mathrm{~cm}$ spaced joints) at KV4, KV6 and KV11. In generally, the joint separation is medium to open. The most of the infill materials are clay, silt with organic matters and growth of vegetation also present. The infill materials are absent in some low separation joints. Clayey filling material is susceptible to expansion and growth of vegetation within joint separation help to further widen of joints. 
Table 1: Rock mass characteristics of the Lesser Himalayan rocks in Dhulikhel-Panchkhal area

\begin{tabular}{|c|c|c|c|c|c|c|c|c|c|c|c|}
\hline Location & Rock type & $\begin{array}{l}* \text { Weather- } \\
\text { ing grade }\end{array}$ & $\begin{array}{l}{ }^{+} \text {Indur- } \\
\text { ation }\end{array}$ & $\begin{array}{l}\text { Discon- } \\
\text { tinuity }\end{array}$ & Attitude & $\begin{array}{l}\text { Persistency } \\
(\mathrm{m})\end{array}$ & $\begin{array}{l}\text { Spacing } \\
(\mathrm{cm})\end{array}$ & $\begin{array}{l}\text { Width } \\
(\mathrm{mm})\end{array}$ & $\begin{array}{l}\text { Rough- } \\
\text { ness }\end{array}$ & $\begin{array}{l}\text { Infilling } \\
\text { materials }\end{array}$ & Slope \\
\hline KV9 & $\begin{array}{l}\text { Meta- } \\
\text { siltstone }\end{array}$ & Ib to II & $\begin{array}{l}\mathrm{H} 2 \text { to } \\
\mathrm{H} 3\end{array}$ & $\begin{array}{l}\text { Bedding } \\
\text { Joint } 1 \\
\text { Joint } 2\end{array}$ & $\begin{array}{l}320 / 65^{\circ} \\
124^{\circ} / 78^{\circ} \\
270^{\circ} / 12^{\circ}\end{array}$ & $\begin{array}{l}>20 \\
8-10 \\
3-5\end{array}$ & $\begin{array}{l}10-25 \\
20-80 \\
15-45\end{array}$ & $\begin{array}{l}3 \\
2 \\
0.5-1\end{array}$ & $\begin{array}{l}8-10 \\
4-6 \\
4-6\end{array}$ & $\begin{array}{l}\text { Clay, silt, organic } \\
\text { Clay } \\
\text { clay }\end{array}$ & $120^{\circ} / 47^{\circ}$ \\
\hline KV8 & $\begin{array}{l}\text { Meta- } \\
\text { sandstone }\end{array}$ & $\mathrm{Ib}$ & $\begin{array}{l}\mathrm{H} 3 \text { to } \\
\mathrm{H} 4\end{array}$ & $\begin{array}{l}\text { Bedding } \\
\text { Joint } 1 \\
\text { Joint } 2 \\
\text { Joint } 3\end{array}$ & $\begin{array}{l}20^{\circ} / 50^{\circ} \\
255^{\circ} / 55^{\circ} \\
195^{\circ} / 60^{\circ} \\
90^{\circ} / 52^{\circ}\end{array}$ & $\begin{array}{l}1-20 \\
10-14 \\
4-5 \\
3-8\end{array}$ & $\begin{array}{l}5-50 \\
20-60 \\
23-76 \\
>100\end{array}$ & $\begin{array}{l}3-5 \\
1-3 \\
1 \\
<1\end{array}$ & $\begin{array}{l}6-8 \\
8-10 \\
6-8 \\
4-6\end{array}$ & $\begin{array}{l}\text { Silt, clay } \\
\text { Clay } \\
\text { clay } \\
-\end{array}$ & $126^{\circ} / 72^{\circ}$ \\
\hline KV7 & $\begin{array}{l}\text { Meta- } \\
\text { sandstone }\end{array}$ & $\mathrm{Ib}$ & H4 & $\begin{array}{l}\text { Bedding } \\
\text { Joint } 1 \\
\text { Joint } 2\end{array}$ & $\begin{array}{l}308^{\circ} / 46^{\circ} \\
200^{\circ} / 85^{\circ} \\
130^{\circ} / 35^{\circ}\end{array}$ & $\begin{array}{l}16-20 \\
10-12 \\
5-7\end{array}$ & $\begin{array}{l}10-50 \\
40-100 \\
20-40\end{array}$ & $\begin{array}{l}2 \\
1-2 \\
2-5\end{array}$ & $\begin{array}{l}8-10 \\
6-8 \\
12-14\end{array}$ & $\begin{array}{l}\text { Clay, organic } \\
\text { clay } \\
\text { Clay, organic }\end{array}$ & $145^{\circ} / 30^{\circ}$ \\
\hline KV6 & $\begin{array}{l}\text { Meta- } \\
\text { sandstone }\end{array}$ & Ib to II & $\begin{array}{l}\mathrm{H} 3 \text { to } \\
\mathrm{H} 4\end{array}$ & $\begin{array}{l}\text { Bedding } \\
\text { Joint } 1 \\
\text { Joint } 2\end{array}$ & $\begin{array}{l}121^{\circ} / 74^{\circ} \\
270^{\circ} / 73^{\circ} \\
15^{\circ} / 55^{\circ}\end{array}$ & $\begin{array}{l}15-20 \\
8-10 \\
3-5\end{array}$ & $\begin{array}{l}8-20 \\
20-50 \\
40-100\end{array}$ & $\begin{array}{l}2-10 \\
1-3 \\
1-2\end{array}$ & $\begin{array}{l}6-8 \\
6-8 \\
10-12\end{array}$ & $\begin{array}{l}\text { Silt, clay } \\
\text { Clay } \\
\text { clay }\end{array}$ & $40^{\circ} / 80^{\circ}$ \\
\hline KV10 & Quartzite & $\mathrm{Ib}$ & H4 & $\begin{array}{l}\text { Bedding } \\
\text { Joint } 1 \\
\text { Joint } 2 \\
\text { Joint } 3\end{array}$ & $\begin{array}{l}235^{\circ} / 67^{\circ} \\
128^{\circ} / 36^{\circ} \\
330^{\circ} / 48^{\circ} \\
155^{\circ} / 85^{\circ}\end{array}$ & $\begin{array}{l}7-10 \\
5-8 \\
2-3 \\
3-4\end{array}$ & $\begin{array}{l}50-80 \\
60-80 \\
50-100 \\
>200\end{array}$ & $\begin{array}{l}1-2 \\
<1 \\
1-3 \\
<1\end{array}$ & $\begin{array}{l}4-6 \\
6-8 \\
6-8 \\
10-12\end{array}$ & $\begin{array}{l}\text { Clay, silt } \\
- \\
\text { Silt, clay } \\
-\end{array}$ & $195^{\circ} / 20^{\circ}$ \\
\hline KV5 & Schist & Ib to II & $\begin{array}{l}\mathrm{H} 3 \text { to } \\
\mathrm{H} 4\end{array}$ & \begin{tabular}{|l} 
Bedding \\
Joint 1 \\
Joint 2 \\
\end{tabular} & $\begin{array}{l}215^{0} / 52^{0} \\
150^{\circ} / 54^{\circ} \\
55^{\circ} / 64^{\circ} \\
\end{array}$ & $\begin{array}{l}20 \\
7-10 \\
5-6 \\
\end{array}$ & $\begin{array}{l}15-50 \\
60-100 \\
100-200 \\
\end{array}$ & $\begin{array}{l}2-3 \\
2-5 \\
1-2\end{array}$ & $\begin{array}{l}6-8 \\
8-10 \\
6-8\end{array}$ & $\begin{array}{l}\text { Clay } \\
\text { Clay, organic } \\
\text { clay }\end{array}$ & $65^{\circ} / 68^{\circ}$ \\
\hline KV4 & Quartzite & Ib to II & $\begin{array}{l}\mathrm{H} 3 \text { to } \\
\mathrm{H} 4\end{array}$ & $\begin{array}{l}\text { Bedding } \\
\text { Joint } 1 \\
\text { Joint } 2\end{array}$ & $\begin{array}{l}220^{\circ} / 40^{\circ} \\
292^{\circ} / 43^{\circ} \\
35^{\circ} / 72^{\circ}\end{array}$ & $\begin{array}{l}2-25 \\
10-12 \\
4-6\end{array}$ & $\begin{array}{l}5-20 \\
20-100 \\
50-200 \\
\end{array}$ & $\begin{array}{l}1-3 \\
2-10 \\
1 \\
\end{array}$ & $\begin{array}{l}6-8 \\
10-12 \\
12-14\end{array}$ & $\begin{array}{l}\text { Clay, silt, organic } \\
\text { clay } \\
-\end{array}$ & $330^{\circ} / 80^{\circ}$ \\
\hline KV3 & Schist & II & $\begin{array}{l}\mathrm{H} 2 \text { to } \\
\mathrm{H} 4\end{array}$ & $\begin{array}{l}\text { Bedding } \\
\mathrm{J}_{1} \\
\mathrm{~J}_{2}\end{array}$ & $\begin{array}{l}240^{\circ} / 50^{\circ} \\
310^{\circ} / 85^{\circ} \\
55^{\circ} / 55^{\circ}\end{array}$ & $\begin{array}{l}8-10 \\
10 \\
3-5\end{array}$ & $\begin{array}{l}20-50 \\
60-100 \\
20-50\end{array}$ & $\begin{array}{l}1-2 \\
2-5 \\
<1\end{array}$ & $\begin{array}{l}8-10 \\
6-8 \\
10-12\end{array}$ & $\begin{array}{l}\text { Clay } \\
\text { Clay, organic } \\
\text { clay }\end{array}$ & $331^{\circ} / 72^{\circ}$ \\
\hline KV13 & Schist & II & H3 & $\begin{array}{l}\text { Bedding } \\
\text { Joint } 1 \\
\text { Joint } 2 \\
\end{array}$ & $\begin{array}{l}225^{\circ} / 56^{\circ} \\
62^{\circ} / 57^{\circ} \\
335^{\circ} / 48^{\circ}\end{array}$ & $\begin{array}{c}>20 \\
5-8 \\
12\end{array}$ & $\begin{array}{l}30-50 \\
50-80 \\
60-120 \\
\end{array}$ & $\begin{array}{l}1-2 \\
0.5-1 \\
1 \\
\end{array}$ & $\begin{array}{l}6-8 \\
12-14 \\
10-12 \\
\end{array}$ & $\begin{array}{l}\text { clay } \\
- \\
\text { clay }\end{array}$ & $73^{\circ} / 62^{\circ}$ \\
\hline KV2 & Schist & Ib to II & $\mathrm{H}_{4}$ & $\begin{array}{l}\text { Bedding } \\
\text { Joint } 1 \\
\text { Joint } 2\end{array}$ & $\begin{array}{l}325^{\circ} / 42^{\circ} \\
130^{\circ} / 48^{\circ} \\
10^{\circ} / 78^{\circ}\end{array}$ & $\begin{array}{l}15-20 \\
15-20 \\
8-12\end{array}$ & $\begin{array}{l}15-30 \\
100-200 \\
50-100 \\
\end{array}$ & $\begin{array}{l}1-2 \\
1-5 \\
<1 \\
\end{array}$ & $\begin{array}{l}6-8 \\
4-6 \\
12-14\end{array}$ & $\begin{array}{l}\text { Clay } \\
\text { Clay, silt, organic } \\
\text { clay }\end{array}$ & $40^{\circ} / 66^{\circ}$ \\
\hline KV1 & Schist & $\mathrm{Ib}$ & $\begin{array}{l}\mathrm{H}_{3} \text { to } \\
\mathrm{H}_{4}\end{array}$ & $\begin{array}{l}\text { Bedding } \\
\mathrm{J} 1 \\
\mathrm{~J} 2\end{array}$ & $\begin{array}{l}270^{\circ} / 54^{\circ} \\
140^{\circ} / 36^{\circ} \\
355^{\circ} / 63^{\circ}\end{array}$ & $\begin{array}{l}>20 \\
12-20 \\
10-15\end{array}$ & $\begin{array}{l}10-25 \\
20-50 \\
20-25\end{array}$ & $\begin{array}{l}>1 \\
<1 \\
<1\end{array}$ & $\begin{array}{l}8-10 \\
10-12 \\
14-16 \\
\end{array}$ & $\begin{array}{l}\text { Silt and clay } \\
\text { Clay, organic } \\
\text { clay }\end{array}$ & $330^{\circ} / 60^{\circ}$ \\
\hline KV11 & Quartzite & Ib to II & H3 & $\begin{array}{l}\text { Bedding } \\
\text { Joint } 1 \\
\text { Joint } 2\end{array}$ & $\begin{array}{l}242^{\circ} / 70^{\circ} \\
0^{\circ} / 68^{\circ} \\
125^{\circ} / 31^{\circ}\end{array}$ & $\begin{array}{l}10 \\
5-8 \\
3-6\end{array}$ & $\begin{array}{l}5-10 \\
30-50 \\
25-60\end{array}$ & $\begin{array}{l}2-10 \\
1-5 \\
2-3\end{array}$ & $\begin{array}{l}6-8 \\
10-12 \\
8-10\end{array}$ & $\begin{array}{l}\text { Clay, organic } \\
\text { Clay, organic } \\
\text { Clay, organic }\end{array}$ & $338^{\circ} / 65^{\circ}$ \\
\hline KV12 & Quartzite & II & H3 & $\begin{array}{l}\text { Bedding } \\
\text { Joint } 1 \\
\text { Joint } 2 \\
\text { Joint } 3\end{array}$ & $\begin{array}{l}245^{\circ} / 46^{\circ} \\
270^{\circ} / 28^{\circ} \\
115^{\circ} / 59^{\circ} \\
52^{\circ} / 45^{\circ}\end{array}$ & $\begin{array}{l}>20 \\
10-15 \\
3-5 \\
4-8\end{array}$ & $\begin{array}{l}20 \\
10-16 \\
8-20 \\
50\end{array}$ & $\begin{array}{l}1-3 \\
2-5 \\
0.5 \\
1\end{array}$ & $\begin{array}{l}4-6 \\
10-12 \\
6-8 \\
12-14\end{array}$ & $\begin{array}{l}\text { Clay, silt, organic } \\
\text { Clay, organic } \\
\text { Clay } \\
-\end{array}$ & $58^{\circ} / 66^{\circ}$ \\
\hline
\end{tabular}

*Weathering grade: $\mathrm{Ib}=$ faintly weathered, II = slightly weathered (after Geological Society of London, 1977)

Induration: H2 = weakly indurated, H3 = indurate, H4 = strongly indurated (after Larsen et. al., 1995) 
The weathering grade of rocks was classified according to weathering classification given by Geological Society of London (1977). The result of field observation shows that most of the rocks on the outer surface fall in grade IB to II. It means that the rock in study area is faintly weathered to slightly weathered. Indurations of samples were measured according to Larson et. al. (1995). The result of degree of induration of rocks at 13 locations shows that the rocks fall on $\mathrm{H} 2$ to $\mathrm{H} 4$, i.e. weakly indurated to strongly indurated. Most of the rocks are $\mathrm{H} 3$ to $\mathrm{H} 4$ which means most rocks are indurated to strongly indurated. Only the rocks at location KV3 and KV9 are weakly indurated to indurated.

\section{Kinematic analysis of rock masses}

Kinematic analysis is a geometric representation of jointed rock mass in an stereographic projection. The angular relationships between discontinuities, angle of friction of the materials and slope surface are applied to determine the potential mode of failure. The study of the discontinuities stereographic projection of major joint sets and slope stability analysis have been done at 4 location of different lithological formation of the study area. Some exposures of rock masses are shown in Fig.11 and Fig. 12.

The area is influenced by the most probable wedge failures as in the locations KV8 and KV12. Plane

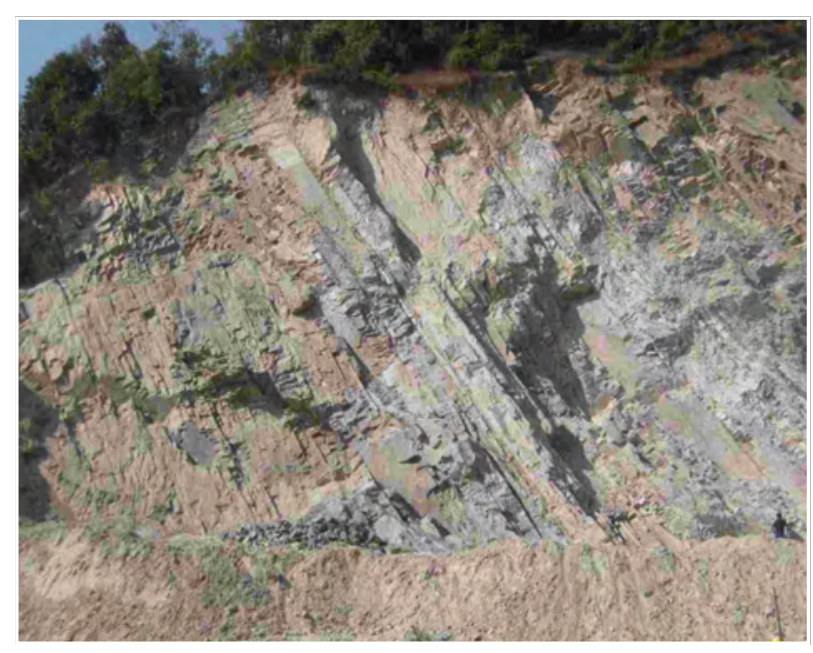

Fig. 11 Quarry site of construction materials at the BP Rajmarg facing SE (location KV8). failure occurs in the rock mass at the location KV5 and KV12. The rocks of the Tistung Formation are affected by the most possibility of day-lighting wedge W2 (Fig. 13a). Possibility of planar failure and toppling failures is absent. A plane failure is seen at KV5 (Markhu Formation) as indicated by $\mathrm{J} 2$, and there is also very little possibility of wedge slide along W1 (Fig. 13b). The Kulekhani Formation is very little affected by a day-lighting wedge, $\mathrm{W} 1$ and a plane failure along J2 (Fig. 13c). A wedge failure and possibility of a toppling failure are detected in the micaceous quartzite of the Kalitar Formation (Fig. 13d).

\section{Rock mass classification}

Bieniawski (1976) published the details of a rock mass classification called the Geomechanics Classification or the rock mass rating (RMR) system. Uniaxial compressive strength, rock quality designation (RQD), spacing of discontinuities, condition of discontinuities, groundwater conditions and orientation of discontinuities are major parameters used to classify a rock mass. The result tabulated (Table 2) shows that the rock mass are classified into fair rock and good rock classes according to the RMR system (Bieniawski, 1989). The RMR value ranges from 50 to 69 . The rock mass at the locations KV9, KV3, KV13, KV11 and $\mathrm{KV} 12$ are fair rock and at the location KV8, KV7, KV6, KV10, KV5, KV4 and KV2 lie within good rock class. The RMR values of the metasiltstone (KV9) and

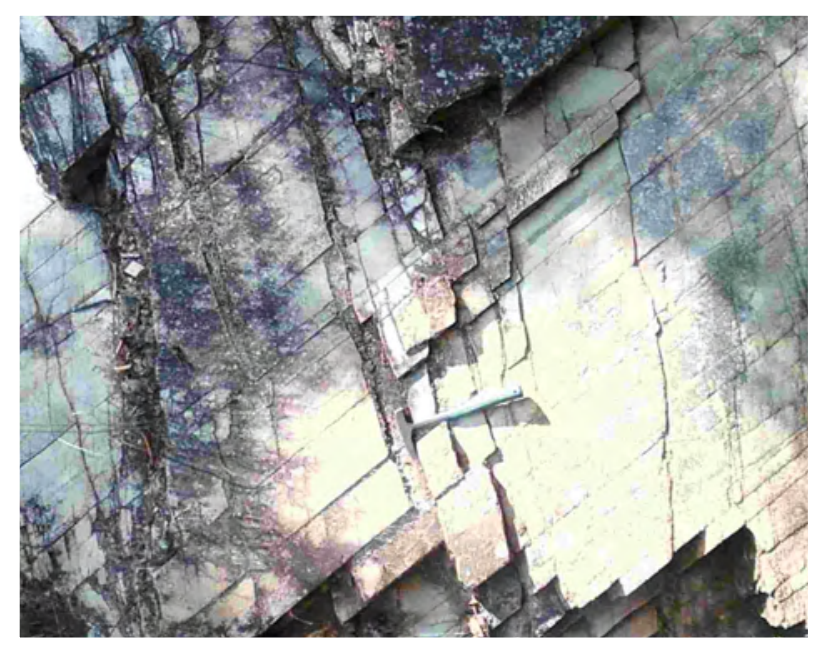

Fig. 12 Highly jointed outcrop of micaceous white quartzite in the Bhotekate Khola of the Kalitar Formation facing SW (location KV12). 


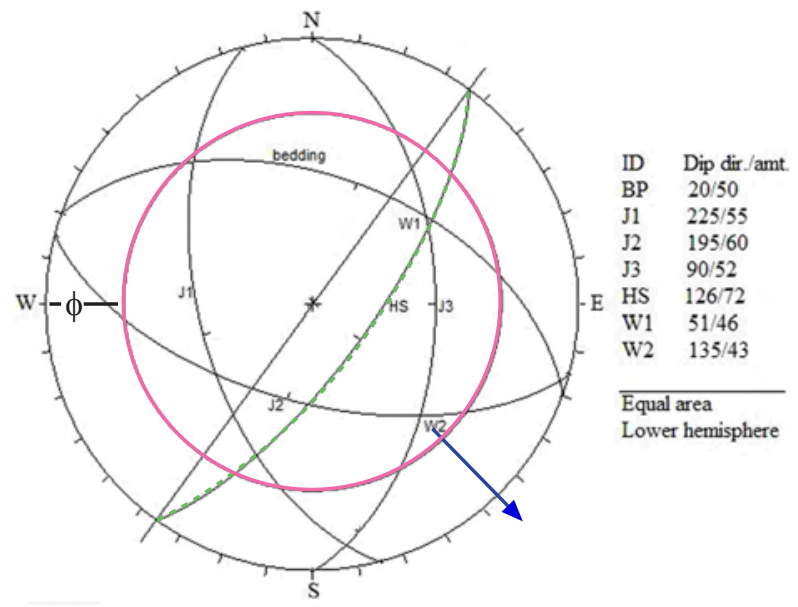

(a)

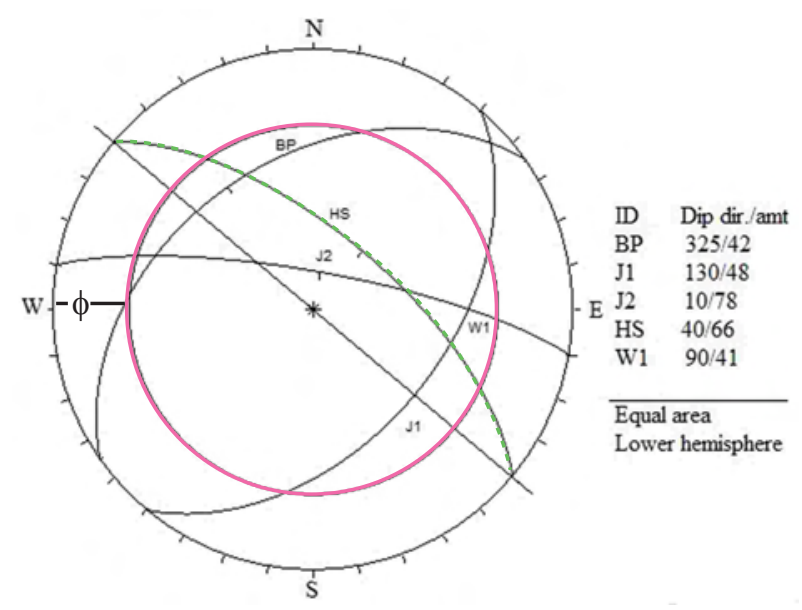

(c)

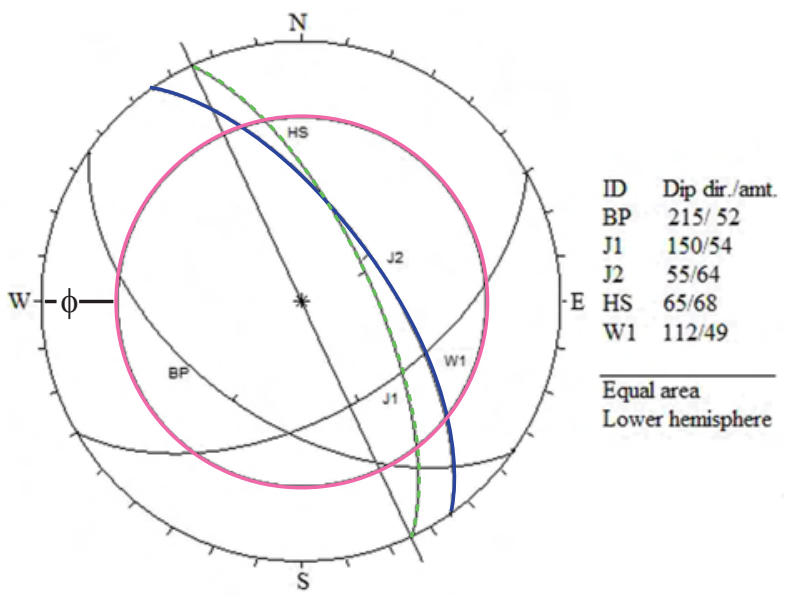

(b)

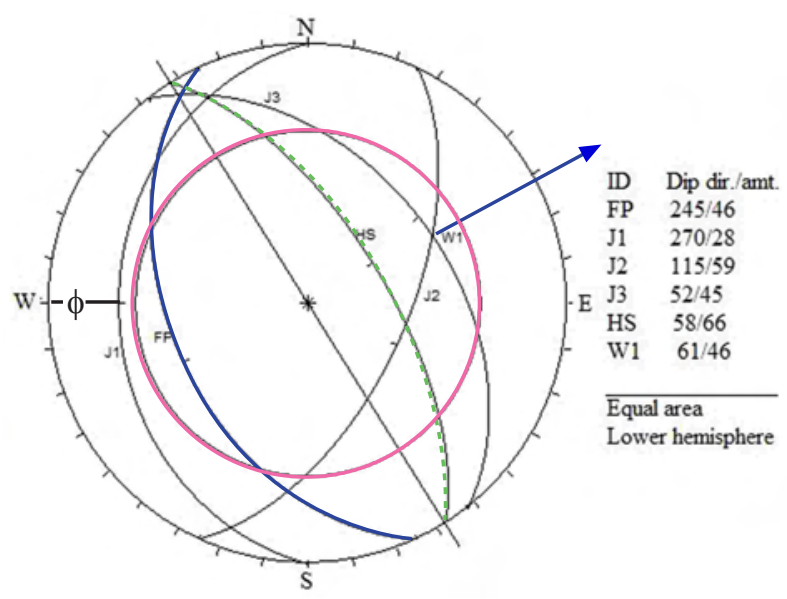

(d)

Fig. 13: Stereographic projections of major discontinuities measured at different locations: (a) At location KV8, the Tistung Formation, (b) At location KV5, the Markhu Formation, showing a potential failure plane (J2), (c) At location KV2, the Kulekhani Formation, and (d) In the Bhotekate Khola (location KV12), the Kalitar Formation indicating a potential wedge (W1) and a potential toppling failure plane (FP). Arrows indicate potential wedges.

micaceous white quartzite of the Kalitar Formation are minimum. Due to the effect of the ground water condition, low spacing and RQD rating (high Jv), the RMR at KV12 is minimum. Although the effect of ground water condition is present, all the parameters are strong in case of the calcareous quartzite of location $\mathrm{KV} 10$, and the RMR value is also maximum.

\section{Intact rock strength and physical properties}

Strength is a fundamental quantitative engineering property of rock specimen. It is the amount of applied stress at rock failure or rupture. The point-load strength indices of different core samples were measured in a laboratory. The strength in axial test direction was determined. The result is given in the Table 3. The UCS values derived after calculation, range from $23.63 \mathrm{MPa}$ in sample KV9 to $217.92 \mathrm{MPa}$ in sample KV6. Thus the rocks can be categorised into five classes according to the intact rock strength classification given by Bieniawski (1975). The rock at the location KV9 is of very low strength, sample KV3 of low strength, sample KV13 of medium strength, samples KV7, KV8, KV10, KV5, KV4, KV2, KV1, KV11 and KV12 are of high strength and KV6 is of very high strength. The uniaxial compressive strength value is greater in metasandstone 
Table 2: Rock mass rating (RMR).

\begin{tabular}{|c|c|c|c|c|c|c|c|c|c|c|c|}
\hline Formation & Location & Rock type & UCS (MPa) & RQD (\%) & $\begin{array}{c}\text { Spacing } \\
(\mathrm{cm})\end{array}$ & $\begin{array}{l}\text { Condition of } \\
\text { discontinuities }\end{array}$ & GW & ondition & RMR & & ck class \\
\hline \multirow{4}{*}{ Tistung } & KV9 & Metasiltstone & $23.63 \quad(2)$ & 58.9 (13) & 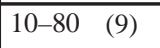 & (11) & Dry & (15) & (50) & III & Fair \\
\hline & KV8 & Metasandstone & $142.56(12)$ & $52.3(13)$ & 20-100 (13) & (17) & Dry & (15) & (68) & II & Good \\
\hline & KV7 & Metasandstone & $152.95(12)$ & $68.8(13)$ & 10-100(12) & (13) & Dry & (15) & (65) & II & Good \\
\hline & KV6 & Metasandstone & $217.92(12)$ & $65.5(13)$ & 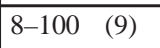 & (14) & Dry & (15) & (63) & III & Good \\
\hline \multirow{4}{*}{ Markhu } & KV10 & Calc-quartzite & $132.57 \quad(12)$ & $75.4(17)$ & $50-200(15)$ & (18) & Wet & (7) & (69) & II & Good \\
\hline & $\overline{\text { KV5 }}$ & Schist & $185.37(12)$ & $68.8(13)$ & 15-200(13) & (12) & Dry & (13) & (65) & II & Good \\
\hline & KV4 & Quartzite & $108.85(12)$ & $58.9(13)$ & 5-200 (11) & (13) & Dry & (15) & (64) & II & Good \\
\hline & KV3 & Schist & $43.57 \quad(4)$ & $68.8(13)$ & $20-100(12)$ & (14) & Dry & (15) & (58) & III & Fair \\
\hline \multirow{3}{*}{ Kulekhani } & KV13 & Sschist & $83.07 \quad(7)$ & 72.1 (13) & $30-120(12)$ & (15) & Wet & (7) & (54) & III & Fair \\
\hline & $\overline{\mathrm{KV} 2}$ & Schist & $127.45(12)$ & 58.9 (13) & $15-200(13)$ & (13) & Dry & (15) & (66) & II & Good \\
\hline & KV1 & Schist & $105.47(12)$ & $68.8(13)$ & $10-50 \quad(9)$ & (16) & Dry & (15) & (62) & II & Good \\
\hline Chisapani & KV11 & Mica-quartzite & $188.55(12)$ & $49 \quad(8)$ & $5-60$ & (13) & Dry & (15) & (57) & III & Fair \\
\hline Kalitar & KV12 & Mica-quartzite & $140.33(12)$ & $45.7(8)$ & $6-50$ & (14) & Wet & (7) & (50) & & Fair \\
\hline
\end{tabular}

*Bieniawski (1989)

Table 3: Results of physical tests of rock samples

\begin{tabular}{|c|l|l|l|l|l|l|l|l|l|l|l|l|l|l|}
\hline S.N. & Test type & KV9 & KV8 & KV7 & KV6 & KV10 & KV5 & KV4 & KV3 & KV13 & KV2 & KV1 & KV11 & KV12 \\
\hline 1 & UCS $(\mathrm{MPa})$ & 23.63 & 142.56 & 152.95 & 217.92 & 132.57 & 185.37 & 108.85 & 43.57 & 83.07 & 127.45 & 105.47 & 188.55 & 140.33 \\
\hline 2 & WAV $(\%)$ & 0.739 & 0.45 & 0.586 & 0.902 & 1.189 & 0.327 & 0.302 & 2.392 & 0.401 & 0.691 & 0.488 & 0.405 & 0.357 \\
\hline 3 & DD $\left(\mathrm{gm} / \mathrm{cm}^{3}\right)$ & 2.591 & 2.658 & 2.525 & 2.308 & 2.483 & 2.743 & 2.673 & 2.359 & 2.735 & 2.645 & 2.644 & 2.569 & 2.599 \\
\hline
\end{tabular}

and quartzite. The schist shows the intermediate value (except KV5), whereas the metasiltstone shows very low strength.

The results of physical properties of core samples such as water absorption value and dry density are listed in Table 3. The water absorption value ranges from 0.302 to $2.392 \%$. These data show that there is no access for water to pass through rock i.e. the rocks are compact enough with negligible pores. The dry density ranges from 2.308 to $2.743 \mathrm{gm} / \mathrm{cm}^{3}$. The dry density of aggregates normally used in construction purpose ranges from 2 to $3 \mathrm{gm} / \mathrm{cm}^{3}$. Aggregates with average dry density of $2.6 \mathrm{gm} / \mathrm{cm}^{3}$ are used in road construction (ASTM, 1994).

\section{CONCLUSIONS}

The study area is characterised by the Upper Nawakot Group and the Bhimphedi Group separated by the ChakRosi Thrust. The Upper Nawakot Group is represented by the Benighat Slate, whereas the Bhimphedi Group is represented by the Raduwa Formation, Bhainsdovan Marble, Kalitar Schist, Kulekhani Formation, Markhu Formation and the Tistung Formation. The strata generally dip southwards and constitute part of the eastern closure of the Mahabharat Synclinorium.

Study area comprises mainly micaceous quartzite, psammitic schist, metasandstone and metasiltstone. The micaceous quartzite is a rock type of the Kalitar Formation, Chisapani quartzite and the Markhu Formation. The Markhu quartzite is slightly calcareous. The psammitic schist is a rock type of the Kulekhani Formation and the Markhu Formation. The metasandstone and metasiltstone are the rock types of the Tistung Formation.

The rock mass consists mainly of three to four major joint sets including the joint parallel to foliation. The discontinuity characteristics indicate that the rocks are blocky in nature, and nearly smooth to rough surface with soft filling aperture. The rock mass is nearly fresh, 
indurated and strong enough showing that the aggregates will have a good stiffness. The slopes are influenced by stable and unstable wedge, plane and toppling failures. The rock masses are classified into fair to good rock classes according to rock mass rating system.

The UCS value ranges from 23.63 and $217.92 \mathrm{MPa}$ showing that rocks have very low strength to very high strength. The water absorption value and dry density ranges from 0.30 to $2.39 \%$ and from 2.31 to 2.74 $\mathrm{gm} / \mathrm{cm}^{3}$, respectively, indicating the rocks having low effective porosity.

\section{ACKNOLEDGEMENTS}

Authors are thankful to Central Department of Geology, Kirtipur and East Management and Engineering service Pvt. Ltd., Nepal for providing laboratory facilities.

\section{REFERENCES}

ASTM 1994, Standard Specification for Transportation Materials and Methods for sampling, Washington D.C.

Barton, N. and Chouby, V., 1977. The shear of rock joints in theory and practice, Vol. 10, pp. 1-54.

Bieniawski, Z.T., 1975. The point load test in Geotechnical Practice: Eng. Geol., Vol. 9, pp. 1-11. http://dx.doi.org/10.1016/0013-7952(75)90024-1

Bieniawski, Z.T., 1976. Rock Mass Classification in Engineering, pp. 97-106.

Bieniawski, Z.T., 1989. Engineering rock mass classifications. John Wiley \& Sons, New York, 251p.

Geological Society London, 1977. Engineering group working party report. The description of rock masses for Engineering Purpose. Vol. 10, pp. 355-388.

Hassani, F.P., Scoble, M.J. and Whittaker, B.N., 1980. Application of point load test to strength determination of rock and proposal for a new size correction chart. Proc. zist vs symp. Rock Mech. pp. 543-553.

ISRM, 1979 suggested methods for determining water content, porosity, density, water absorption and related properties and swelling and slake-durability index properties. Intl. soc. Rock, mech. min. sci. and Geomech. Abstr., Vol 16, pp. 141-156.
Kansakar, D.R., 1980. Geology and structure of the Panchkhal-Dolalghat region in Central Nepal and their bearing on the regional tectonic framework. A Ph.D thesis, Dept. of Geology.; M.S University of Baroda, India. p 256.

Kayastha Y. B., 1995. General geology of the Timal danda and its surrounding area, Lesser Himalaya, Central Nepal, Kavre district. Dissertation submitted to Central Department of Geology, T.U., pp. 72.

Khanal, S. and Tamrakar, N.K., 2009. Evaluation and quality of crushed- limestone and siltsone for road aggregates, Bulletin of Department of Geology, T.U., Kathmandu, Nepal. Vol. 12, pp. 29-42.

Larsen, G. Federiksen, J. Villumsen, A. Federicia, J. Gravesen, P. Foged, N., Knudsen, B., and Baumann, J. 1995. A guide to engineering Geological soil description. Denish Geotecnical Society, Bulletin 1.

Maharjan, D.K. and Tamrakar, N.K., 2003. Quality of Siltstones for Concrete Aggregates from Nallu Khola Area, Kathmandu, Jour. Nepal Geol. Soc., vol. 30, pp. 167-176.

Stöcklin, J., Bhattarai, K.D., 1977. Geology of the Kathmandu area and central Mahabharat range, Nepal Himalaya. Report of Department of Mines and Geology/ UNDP (unpublished), 86p.

Tamrakar, N.K., Paudayal, K.N. and Dhital M.R. 1997, Geology of the Jhiku Khola Watershed area (unpublished report submitted to Mountain Risk Engineering Unit, Tribhuvan University). 